\title{
FLASHCARD GAMES AS A LEARNING TOOL : INTERNALIZING THE PRACTICAL VALUES OF PANCASILA
}

\section{Aryaning Arya Kresna}

Pradita University, Indonesia

E-mail: arya.kresna@pradita.ac.id

\begin{tabular}{|c|c|}
\hline ART & ABSTRACT \\
\hline $\begin{array}{l}\text { Received: } \\
\text { November, 26 } \\
2021 \\
\text { Revised: } \\
\text { December, 17th } \\
2021 \\
\text { Approved: } \\
\text { December, 19th } \\
2021\end{array}$ & $\begin{array}{l}\text { This paper discusses new possible efforts to internalize the } \\
\text { values of Pancasila through a flashcard game. This is } \\
\text { because these values can be taught in a fun way through } \\
\text { games. Internalization of these values can be done } \\
\text { explicitly or implicitly in several aspects of the game, } \\
\text { namely the rules of the game, the characters, and the } \\
\text { narrative. The discussion begins with a hermeneutic } \\
\text { analysis of Pancasila values that will be internalized to the } \\
\text { game participants. The method used was hermeneutics as } \\
\text { a tool of philosophical analysis to obtain a practical } \\
\text { concept of the philosophical values of Pancasila. } \\
\text { Furthermore, these practical values will be used in the } \\
\text { effort to internalize values through flashcards games. The } \\
\text { results of the analysis were simplified so that they can be } \\
\text { used as a narrative and reference for the game, as well as } \\
\text { a reference for game rules. The conclusion is that the } \\
\text { flashcards game can be used as a means of internalizing } \\
\text { the values of Pancasila if these values can be } \\
\text { comprehensively expressed in the narrative, flow, and } \\
\text { rules of the game. }\end{array}$ \\
\hline KEYWORDS & Games, Flashcards, Internalization, Pancasila, Values \\
\hline c) (i) (2) & ternational \\
\hline
\end{tabular}

How to cite:

E-ISSN:

Eduvest. 1(12): 1488-1998

Published by: $\quad$ https://greenpublisher.id/ 


\section{INTRODUCTION}

Indonesia is a nation-state that was build after World War II. As a new nation with so many aspects of diversity, Indonesia needed "common reason" which could be used as a common paradigm to unite tribes, languages, and religious belief. Luckily, Indonesia's founding fathers came up with a new discourse called Pancasila. Since the beginning of its independence from imperialism and colonialism, Pancasila has been a binding force within this young and has become the philosophy of the nation.

However nowadays, Pancasila seems to be increasingly abandoned by its adherents, and therefore new efforts are needed to revive it. The revival of Pancasila can be done through different media. The results of the Strategis Nasional Unggulan Multitahun (Multi-year National Excellent Strategic) research conducted by the Center for Pancasila Studies UGM, which was funded by DIKTI in 2012-2013, have provided a new understanding that it is easier to cultivate Pancasila as a way of life and national ideology through multimedia and games rather than classroom citation.

The most important factor is that in internalizing these values, the paradigm for publicizing Pancasila must abandon the New Order-style indoctrination method and use a new way, namely through the method of play.The game to be used as a learning tool and value internalization must be specially designed from all aspects to be effective.

\section{RESEARCH METHOD}

The method used is hermeneutics as a tool of philosophical analysis in order to obtain a practical concept of the philosophical values of Pancasila. Furthermore, these practical values will be used in the effort to internalize values through flashcards games.

\section{RESULT AND DISCUSSION}

\section{A. Pancasila as a Method and Philosophical System}

Since the beginning, Pancasila has always been claimed as a crystallization of the noble values of the Indonesian. However, reality does not seem to align with the values.. These words are less important so please delete them deviations from Pancasila values in political, economic, socio-cultural, and religious practices must be immediately addressed. The problems faced by this nation is the level of relevance of Pancasila values in everyday life. An understanding of the values of Pancasila must be practical and freely interpreted logically (Aryaning Arya Kresna, 2013).

Pursuing the Philosophy of Pancasila leaves the understanding that Pancasila can be understood as a system of beliefs and, at the same time, as a method of thinking. By getting deeper into Pancasila through philosophy, it is found that the linkage between Pancasila as a system of thought and as a method for conducting assessments is too complicated, although it needs to be taught to all Indonesians as its main constituent, Pancasila needs to be simplified. The question that arises is, which parts of Pancasila can be simplified so that it can be more easily understood, especially by future generations at the primary school level?

Understanding Pancasila as an ideology will be easier than if trying to understand Pancasila a philosophical system. As a philosophical system, Pancasila is often trapped in different philosophical concepts, which is also a source of values and it is often ambiguous in its basic terms, for example, regarding the metaphysical, anthropological concept of Pancasila, namely Monopluralist Man. 
Particularly, this concept needs to be taught to all Indonesians. However, It is only taught formally and usually at the higher education level because Pancasila, as a philosophical system, must be understood holistically. However, as a method of assessment, teaching about what's good or bad that refers to the values of Pancasila, must be started early, given the importance of the position of Pancasila. Therefore, the choice to simplify Pancasila leads to the interpretation of these values in real life (Aryaning Arya Kresna, 2016)

\section{B. Values of Pancasila}

The points of Pancasila are a practical understanding that provides guidelines for a person's behavior, but the sentences that appear are still too abstract, too normative which makes it difficult to understand and internalize for learners. Pancasila values that can be used as guidelines are those that can be implemented and are easy to understand, such as honesty, equality, mutual coperation, mutual assistance. These positive values have active consequences, meaning that their activities can be implemented in real life (Darmaputera, 1988). The practical values of Pancasila can be internalized through games because they are psychomotoric. Students can learn together and build understanding with other participants To validate the understanding. The aspects that need to be considered in the game to be used in value internalization are 1). Game rules, 2). The narrative that appears, and 3). Character in the game figure (Hirumi, Appelman, Rieber, \& van Eck, 2010). These 4 aspects must be formulated and designed in such a way that when it is played, all players can enjoy the game, apply game rules, amused, and in the end will exemplify Pancasila values in the game.

\section{Character, Narrative, and Rules of the Game}

Character is an absolute factor in education because learning activities are actually an extension of the human mimetic concept (Lugmayr et al., 2017). Like every form of self-expression, humans try to understand themselves by imitating (mimesis) and symbolizing all human behavior (Graeber, 2013). In an effort to understand himself, humans create a gap between their consciousness and phenomena in order to understand themselves more fully. So that through this narrative, he is able to see himself more clearly. If we look closely, this is a reflection of human life, a kind of the theme of reflection and abstraction of human life, which is understood as a human way of interacting with environmental situations, fellow humans, and themselves.

(Aristotle, 2006) argued that humans are mimesis about their nature. In chapter 4 of Aristotle's Poetics, he wrote that the essential pleasure that every human being achieves when mimesis is "learning and thinking." Aristotle argues that literary mimesis is to represent a complete and continuous action from the beginning, the content, and the conclusion. All three are connected by necessity and possibility.

According to (Broadie, 1991), the emotions that appear in observing a person's character are human attempts to understand himself. For example, a teenager who watched the coverage of the E-KTP corruption case that dragged the names of DPR members from certain commissions. The teenager feels angry watching these events in the coverage, but he will understand that one of the fastest ways to get wealth is to become representatives of the people, get involved in corruption cases, and still be able to continue to dodge, arguing loudly, and insisting that he is innocent. Furthermore, it was up to him whether he would imitate the corrupt behavior or instead save it as a despicable event that he would not replicate. 


\section{Aryaning Arya Kresna}

Since childhood, humans learn to imitate what they see, and this sense of experience creates pleasure and enjoyment of their own. Through mimetics, people personify themselves, and at the same time, they can become themselves more fully. Through mimetics, humans can better position themselves in social relations between individuals, as well as gain the ability to perform abstraction through reflection on self-awareness and their position as a social being as well as an individual.

This mimetic process in the understanding of the Javanese view of the world is called "introspection" and "tepo seliro". When among society there is someone with a good character and qualifications similar to their daily lives, they are mistreated by other people or institutions, experience lousy luck, suffer and suffer, society no longer just stares, but they internalize the character into their lives and begin to be influenced and carried away the narrative and plot contained in the coverage (Brian Kresna, 2011).

This stage of gratification and release is what Aristotle called katharsis. However, this term has always been a topic of debate among philosophers and art experts. There are at least three kinds of analysis on the concept of catharsis, namely medically, morally, and cognitively, but so far, only cognitive analysis is considered important enough to be observed.

This mimetic human condition requires a strong character to become a role model and benchmark. Learning for children aged 8-10 years requires role models for their character building. The past of the Indonesian people, especially the Javanese people, used the epics of Ramayana and Mahabarata along with Rahwana, Rama, Shinta, Kumbakarna, Pandawa, Kurawa, Resi Drona, Sengkuni, and other figures to interpret their lives and educate the character of future generations. This is also needed in current conditions, especially to carry out character education based on Pancasila values. Children aged 8-10 years need an example from a character with Pancasila values. If the values are not found in the real world, it is appropriate to create a fictional character who has the character and behaves according to the Pancasila.

Once characters have been defined, a narrative must be structured to show the characters' best performance. A narrative is discourse that tries to tell an event as if the reader saw or experienced the event himself. Therefore, the most crucial element in a narrative is the element of action or action. What happens is none other than the actions people do over a period. The narrative tells more about a dynamic life in a time series (Takrifin, 2017).

The narrative's ability to shape values lies in its freedom. As a fictional narrative, a story can amaze viewers and inspire how humans should act when they experience the same life story as a character. Human ability to empathize can be triggered by a narrative that provokes compassion, and a character always hit by a disaster. At the same time, optimism can be transmitted through the narrative of courage and intelligence and ingenious and robust character. However, the narrative and the characters are only able to tell and inspire. When character building through value cultivation must be carried out, students must be directly involved in the praxis (Dickey, 2006). Therefore, cultivating values through games needs to be equipped with appropriate game rules and support for the character-building process.

The rules of the game play a big part in the character's educational efforts through the game. Rules give you the shape and flow of the game. In these rules, the purpose of a game can be determined from the beginning. Rules give direction to the narrative and the steps a character takes, in order to make the game meaningful. A game can be used as a way of shaping the character of its players if the goal is to inspire and educate players to adhere to the values of kindness that apply in society. Honesty, and integrity, discipline and obedience, can be taught when the rules of the game are indeed made for such purpose (Salen, 2004). Therefore, rules, along with narrative and character are the most important aspects here. 


\section{Flashcards Game}

The flashcards game is considered quite capable of being a means of internalizing the practical values of Pancasila because, in addition to inviting players to play in groups, the advantages of picture cards lie precisely in the image they carry. Good pictures and images, and strong character depiction, will make it easier for players' imagination to develop together. Because they are visual in nature, picture cards simultaneously make it easier for players to narrate the game and compromise the narrative. This shows the advantages of the flashcardsgame compared to other games. In addition to the character and narrative skills, the flashcardsgame includes the advantages of storytelling, but at the same time lets the players create their own narrative. (Turner \& Martinek, 1999)

Flash card games are very likely to be a means of character building. As in online video games, Gee explains six reasons why someone plays 1). the satisfaction of completing the task, 2). overcome obstacles and challenges. 3). daily entertainment, 4). new fantasy, 5). interaction with friends and family, and 6). curiosity. So the conclusion put forward is to play both for mental health, humanity, and learning. Although many studies show a low influence on learning performance, the good side of play, especially as a means of learning, turns out to be very significant. (Gee, 2008).

This pictorial card game that is deliberately designed to internalize the practical values of Pancasila is called "Pancasila, The Card Game." This flashcardsgame is designed to be as simple as possible so that it can be played and understood easily by players, as shown in the image below.

Image: III.1.

Title: Pancasila The Card Game Source: Author

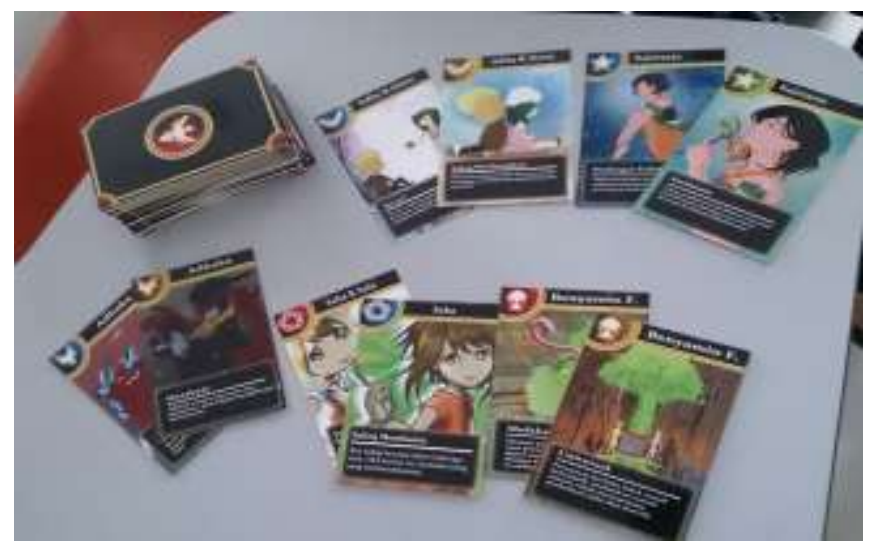

The card game is very important because it allows the players to think, talk, act, and even live in the game. The players can role-play and become any character in the game. This extraordinary virtual world is what makes card games a great place to learn. So it can be concluded that by creating a virtual world of its own, card games combine knowing and doing, caring, as well as being. The card game brings players to create selfidentity and environment and make sense of their lives because learning about values and assessments is carried out simultaneously and effectively. (Shaffer et al, 2004)

\section{E. Card Making Scheme}

Pancasila values that have been taught from elementary to high school. + Pancasila values from everyday life.<smiles>C1CCCC1</smiles>

Brainstorm game rules, sketches.<smiles>C1CCCC1</smiles> 


\section{Aryaning Arya Kresna}

The finished product is a picture card.

The first step is to imagine a figure/character which is suitable and in accordance with the points of Pancasila (in the example of the fourth principle, democracy led by wisdom in deliberation/representation). The 4th principle is depicted as a bull in the shield of the Garuda Pancasila. This bull will be used as a character in the card game.

Next is to select appropriate values to illustrate. It is at this time that the Pancasila values that must be simplified can be included in the card game. The character that appears in the figure of a bull is wisdom, because when living in a group, the bull does not form a group hierarchy based on power, but on its function in the group.

Next, the bull figure is illustrated to make it more interesting. The name of this bull figure is Adhaka, chosen from the Sanskrit word Adaka which means bull. The addition of the letter $\mathrm{H}$ is given to become a new name that has an element of myth in it. The ability of this Adhaka card is Equality. In accordance with the value of the 4th principle, there is the value of wisdom and wisdom. It is hoped that the ability of this card can stimulate wisdom in players. Equality is meant so that players understand that everything has consequences, and that is without exception. The process of forming a character in a bull figure can be seen in the image below:

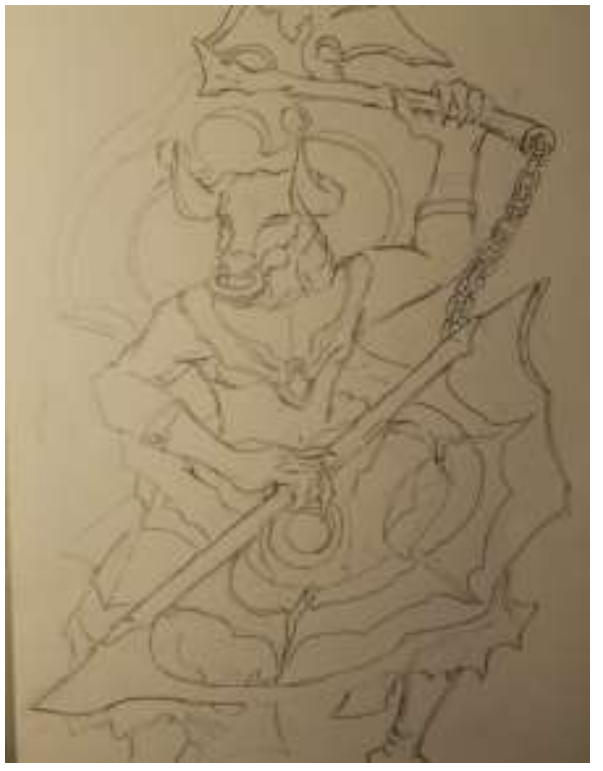

Image : III.2. Initial sketch

Source : the author

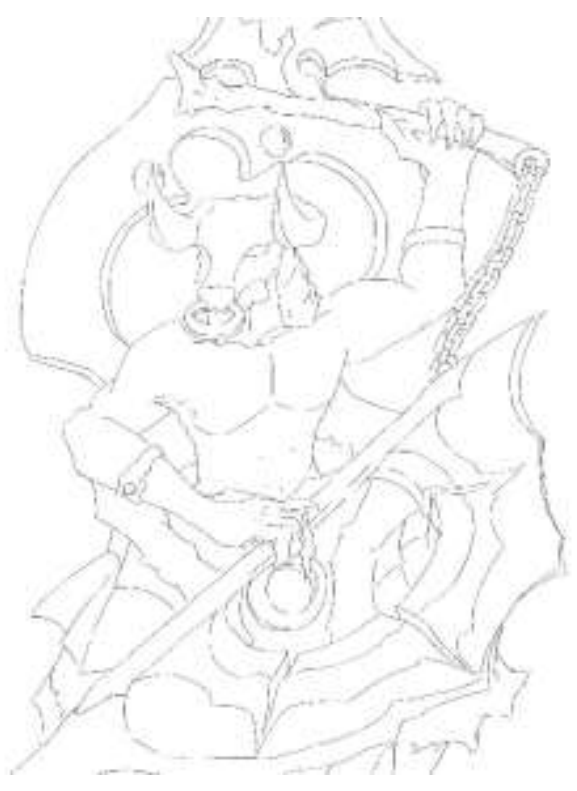

Image :III.3. Digital Sketch Source : the author 


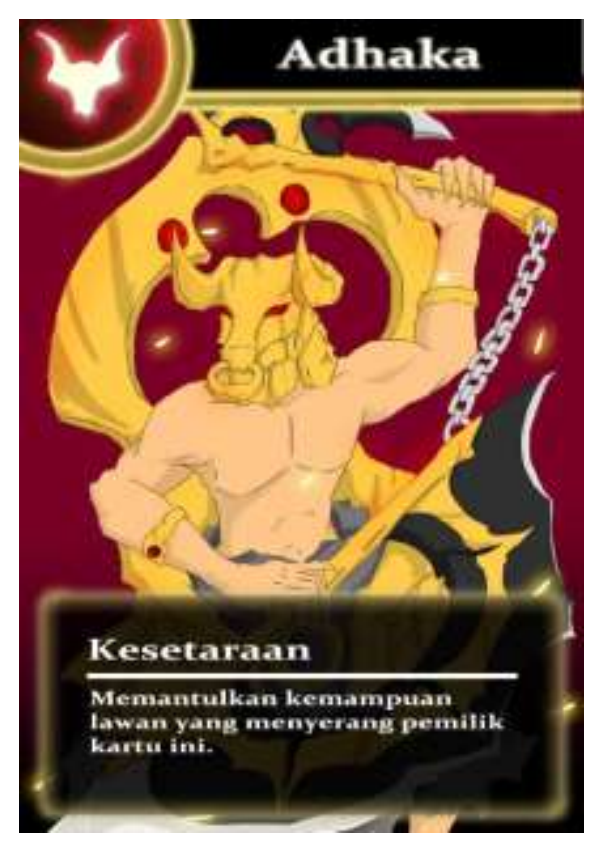

Image : III.4 Final (front)

Source : the author

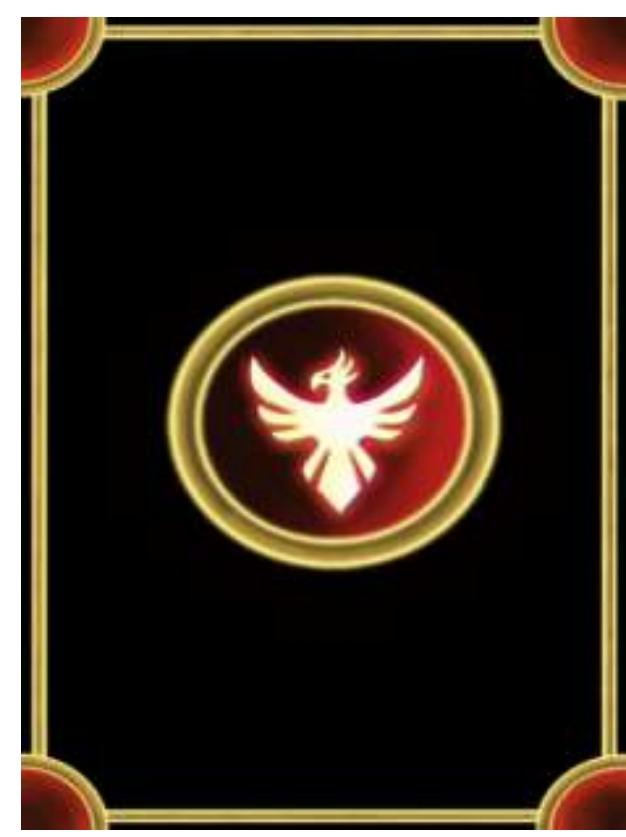

$$
\begin{array}{ll}
\text { Image } & : \text { III.5. Final (back) } \\
\text { Source } & : \text { the author }
\end{array}
$$

\section{F. Game Rules}

- Equipment:

One set of Pancasila The Card Game consists of 75 picture cards (15-star series cards, 15 bull series cards, 15 banyan series cards, 15 chain series cards, and 15 rice and cotton series cards).

- The number of players: teacher/parent)

2 - 5 people. (aged 6 years and over and required a game supervisor such as a

- Preparation:

Each player gets 5 cards randomly at the beginning of the game. The remaining cards are arranged to face down like a deck.

- How to play:

Each round, the player takes 1 card from the deck and discards 1 card from the hand. The maximum card in hand is 5 cards. Alternatively, use the card abilities as written on the card.

Take cards for each round until a player collects 1 set of Pancasila colors.

- Game Objectives:

Introducing and instilling the basic state of Pancasila to the community by playing cards.

- The score of the Game:

The unity and integrity of Pancasila. The Pancasila system, which is a unity, consists of principles that do not contradict each other.

The unity of Pancasila is organic. The existing principles cannot be partially remembered, cannot be eliminated.

- Principles of Pancasila: 


\section{Aryaning Arya Kresna}

○ The One and Only Godhead (Star)

- Just and civilized humanity (Chain)

- Indonesian Unity (Banyan)

- Population led by wisdom in deliberation/representation (Bull)

- Victory

- Social justice for all Indonesian people (Rice and Cotton)

The player who first collects 5 cards from the 5 Pancasila principles of the same color.

Figures and Characters in Picture Cards

- The first principle: Belief in Supreme God

The star symbol in the First Principles is represented by a female figure named Kajoraras, derived from the name Kajor, Kejora, which refers to the Star. The characters that appear are harmony, tolerance, piety, and so forth.

$\begin{array}{ll}\text { Image } & \text { : III.6 Star } \\ \text { Source } & \text { : The author }\end{array}$

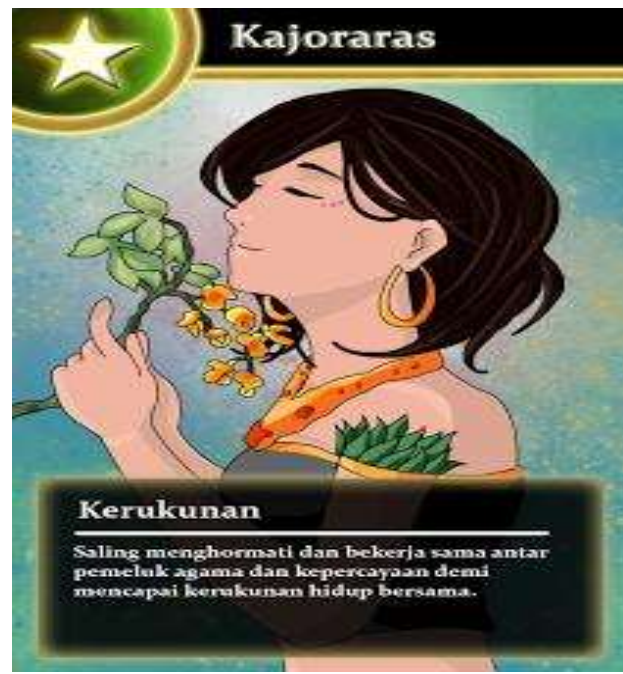

- Second principle: A Just and Civilized Humanity

The chain symbol in the Second Precept is represented by a pair of humans as the embodiment of two chain forms, namely squares and oblongs. The two children are named Saba and Sabi. The characters that appear are harmony, helping, fair and civilized

Image : III.6 Chain

Source : The author

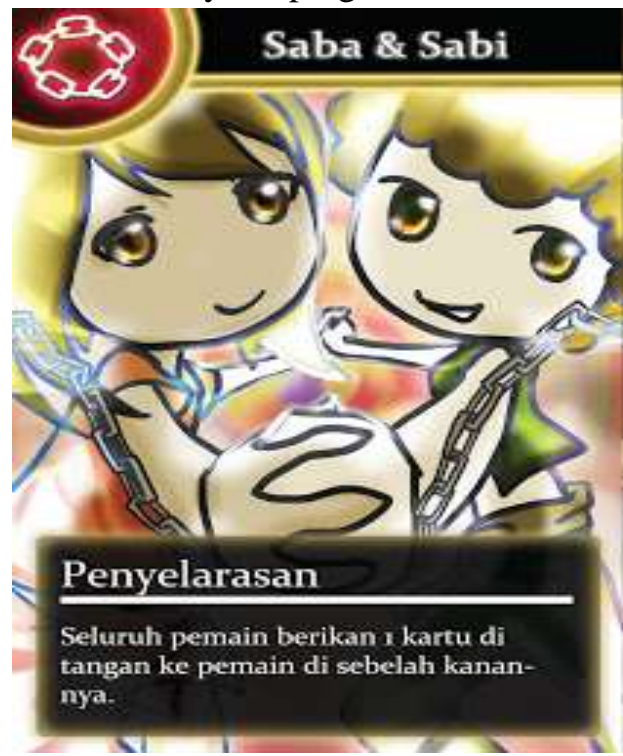




\section{- Third principle: Unity of Indonesia}

A living Banyan tree represents the Banyan symbol in the third principle. This tree is called Benyamin F, which is the Latin name Banyan. The character that is carried is solid, nurturing, and the source of life.

Image : III.6 Banyan Tree

Source : The author

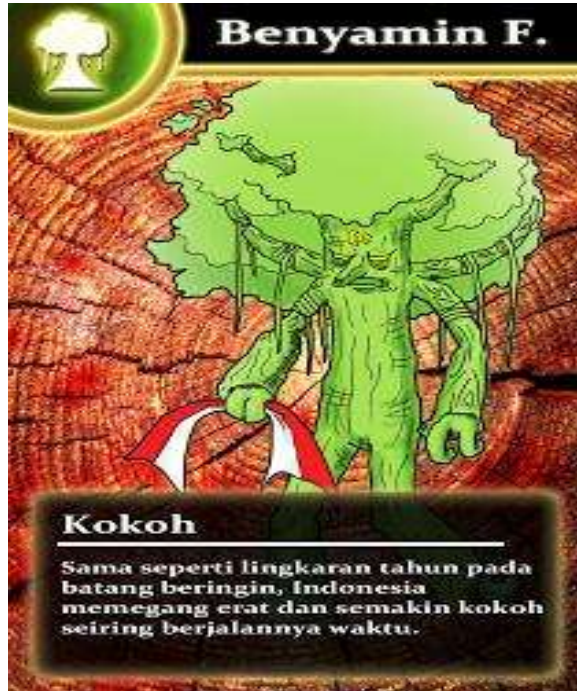

- The fourth principle: Democracy led by the inner wisdom in Deliberation / Representation

The bull, in the fourth principle, is represented by the figure of Adhaka, taken from the Sanskrit language with the same meaning. The characters that appear are equality and society.

Image: III.9. Bull.

Source: Author

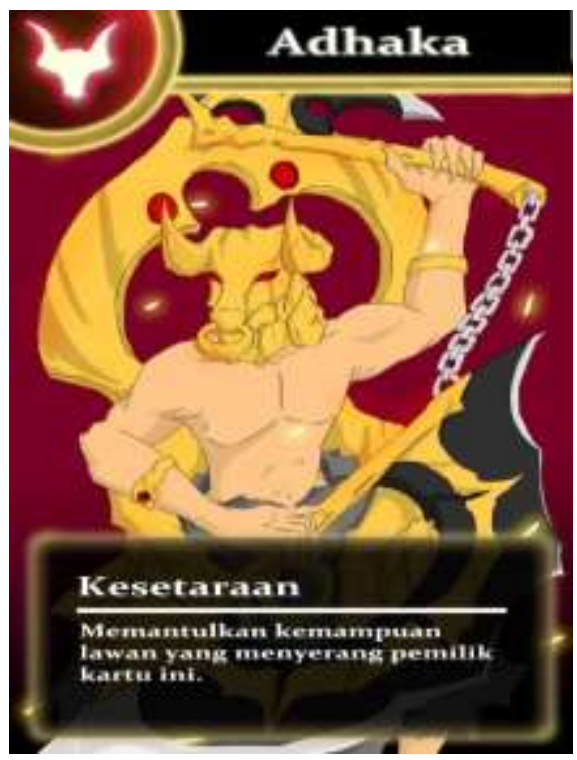

- The fifth principle: Social justice for the entire people of Indonesia

The symbol for rice and cotton in the fifth principle is represented by a pair of little fairies, named Adlay and Alana; their names are taken from the Latin words rice and cotton. The characters that appear are mutual need, share, and give in to win. 
Image : III.8. Rice-Cotton.
Source $:$ the author

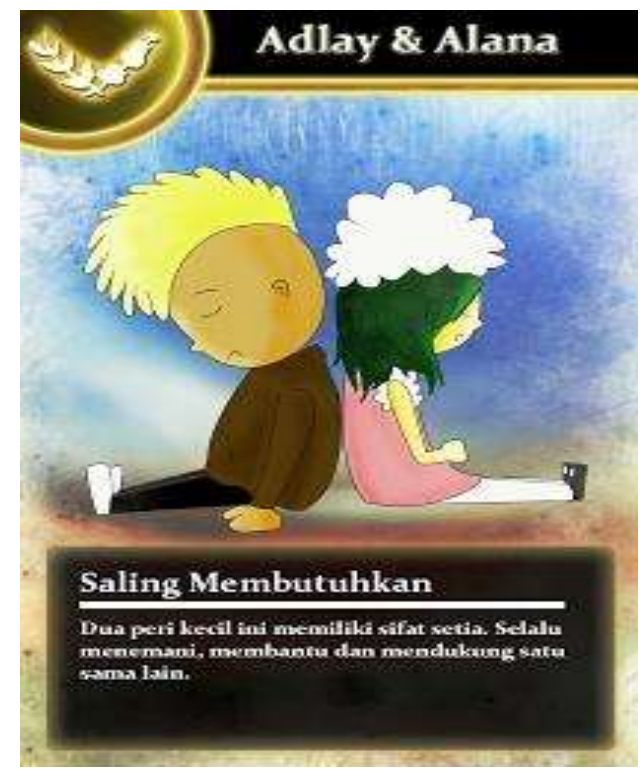

\section{CONCLUSION}

Flash card game can be a means of internalizing the practical values of Pancasila, because of its visual nature, it can stimulate players to create a narrative in playing so that players can enjoy the game. At the same time, obeying the rules of the game and all the sanctions can train the players' sportsmanship and honesty. All of these predicates can be excellent triggers in an effort to internalize the practical values of Pancasila in a fun way.

\section{REFERENCES}

Aristotle. (2006). Poetics. ReadHowYouWant. com.

Broadie, Sarah. (1991). Ethics with aristotle. Oxford University Press on Demand. Darmaputera, Eka. (1988). Pancasila and the search for identity and modernity in Indonesian society: A cultural and ethical analysis. Brill.

Dickey, Michele D. (2006). Game design narrative for learning: Appropriating adventure game design narrative devices and techniques for the design of interactive learning environments. Educational Technology Research and Development, 54(3), 245263. https://doi.org/10.1007/s11423-006-8806-y

Gee, James Paul. (2008). Learning and Games. The Ecology of Games: Connecting Youth, Games, and Learning. The Mit Press, 21-40. https://doi.org/10.1162/dmal.9780262693646.021

Graeber, David. (2013). It is value that brings universes into being. HAU: Journal of Ethnographic Theory, 3(2), 219-243.

Hirumi, Atsusi, Appelman, Bob, Rieber, Lloyd, \& van Eck, Richard. (2010). Preparing Instructional Designers for Game-Based Learning: Part I. TechTrends, 54(3), $27-$ 37. https://doi.org/10.1007/s11528-010-0400-9

Kresna, Aryaning Arya. (2013). Pembentukan Karakter Generasi Muda Berwawasan Nilai-nilai Pancasila Melalui Video Game Bertema RPG. Arete, 2(2). 
Kresna, Aryaning Arya. (2016). Etika, Ideologi dan Identitas Nasional: Pancasila \& Kewarganegaraa (1st ed.). Jogjakarta: Lembaga Ladang Kata.

Kresna, Brian. (2011). Studi tentang pelaksanaan pembelajaran pendidikan jasmani materi lari jarak pendek kelas X di SMK Negeri 6 Malang. Universitas Negeri Malang.

Lugmayr, Artur, Sutinen, Erkki, Suhonen, Jarkko, Sedano, Carolina Islas, Hlavacs, Helmut, \& Montero, Calkin Suero. (2017). Serious storytelling-a first definition and review. Multimedia Tools and Applications, 76(14), 15707-15733.

Salen, Katie and Eric Zimmerman. (2004). Rules of Play - Game Design Fundamentals. Massachusetts London, England: The MIT Press Cambridge.

Takrifin, Ahmad. (2017). TANGGUNG JAWAB ILMU PENGETAHUAN: Pergulatan Antara Kaum Pragmatis dan Puritan-Elitis. RELIGIA.

Turner, Adrian P., \& Martinek, Thomas J. (1999). An investigation into teaching games for understanding: Effects on skill, knowledge, and game play. Research Quarterly for Exercise and Sport, 70(3), 286-296.

https://doi.org/10.1080/02701367.1999.10608047 